\title{
The Rong Ngeng of the Andaman Coast: History, Ecology, and the Preservation of a Traditional Performing Art
}

\author{
Lawrence Ross (ลอเรนซ์ รอส) \\ Senior Lecturer, Academy of Malay Studies, Department of Socio-culture \\ and Malay Arts, University of Malaya, Kuala Lumpur, Malaysia \\ lawrence.apm@gmail.com
}

\begin{abstract}
This article examines recent grassroots strategies for preserving traditional performing arts along southern Thailand's Andaman Sea Coast, focusing on rong ngeng, an idiomatic form of social dance and music, widely popular there in the post-World War Two years. Between 1935 and 1960 a small, mixed cohort of rural performing artists created networks of communities, scattered on Thai-Andaman, with a distinctive regional culture based in the shared repertoire of songs and dances they adapted, created an innovative lyrical style called phleng tanyong (Tanyong song), and a star system that turned village performers into local celebrities (Ross 2017, 68). More than a mere vibrant, short-lived micro-tradition which declined in the wake of a growing, hegemonic pan-Thai performing arts culture, however, rong ngeng has, since the 200os, experienced a revival. The new incarnation was tied to economics, nostalgia, and a reawakening of local identity. Using a broadly cultural ecology approach which draws on more than a decade of fieldwork in the Thailand-Malaysia border region, oral accounts of rong ngeng performers, past and present, and comparisons with performance practices across the regions, this paper argues that efforts toward revival and sustainability have seen their greatest success among communities that possess several characteristics, including strong historical and genealogical links to erstwhile cultural practices, participatory forms of entertainment, and the ability among its members to articulate the relevance of performing arts to the society-at-large.
\end{abstract}




\section{Keywords}

rong ngeng - traditional performing art - Thailand - Andaman Sea - cultural preservation - cultural ecology - oral history - sustainability

บทคัดย่อ

รองเง็งบนฝั่งทะเลอันดามัน: ประวัติศาสตร์ นิเวศวิทยา และการอนุรักษ์ศิลปะการแสดง แบบยั่งยืน

บทความนี้ศึกษายุทธศาสตร์รากหญ้าเพื่ออนุรักษ์ศิลปะการแสดงดั้งเดิมตามชายฝั่งทะเลอันดามัน ของไทย โดยเน้นรองเง็งซึ่งเป็นการร่ายรำและร้องเพลงของกลุ่มดนตรีที่มีลักษณะเฉพาะ และเป็น ที่นิยมอย่างกว้างขวางในช่วงหลังสงครามโลกครั้งที่สองเป็นต้นมา ช่วงระหว่างปี พ.ศ. $2478-$ 2503 กลุ่มศิลปินนักแสดงที่หลากหลายกลุ่มเล็กกลุ่มหนึ่งในชนบทตามชายฝั่งอันดามัน ได้รวมตัว กันเป็นเครือข่ายวัฒนธรรมพื้นบ้านที่โดดเด่นจากพื้นฐานร่วมกันในเรื่องบทเพลงและการร่ายรำ และได้สร้างสรรค์ลำนำเพลงใหม่ใช้ชื่อว่า เพลงตันหยง และสร้างระบบที่เปลี่ยนนักแสดงใน หมู่บ้านให้กลายเป็นดาวดวงเด่นของท้องถิ่น การเกิดใหมู่นี้เชื่อมโยงกับเศรษฐูศาสตร์ ความคิด คำนึงถึงอดีตและการปลุกอัตลักษณ์ขึ้นมาใหม่ อย่างไรก็ดี ตั้งแต่ราวปี พ.ศ. 2543 เป็นต้นมา รองเง็ง ที่ทำท่าจะสูญหายไปในแถบวัฒนธรรมขนาดเล็กที่มีอายุสั้นๆ, ท่ามกลางกระแสวัฒนธรรมการ แสดงทั่วไทย (pan-Thai) ที่เป็นกระแสชื้นำ ก็ฟื้นคืนชีพกลับขึ้นมาอีกครั้ง บทความนี้ใช้วิวีการ ทางนิเวศวิทยาวัฒนธรรมแบบกว้างๆ และการวิจัยภาคสนามที่ทำกันมานานกว่าทศวรรษในพื้นที่ ชายแดนไทย-มาเลเซีย โดยการสัมภาษณ์นักแสดงรองเง็งทั้งอดีตและปัจจุบัน รวมทั้งมีการเปรียบ เทียบการแสดงถิ่นต่างๆ ในภูมิภาค บทความนี้เสนอว่าความพยายามในการฟื้นฟูและรักษาความ ยั่งยืนไว้ต่อไปนั้น ประสบความสำเร็จสูงในชุมชนที่มีความเข้มแข็งในด้านประวัติความเป็นมา และความสัมพันธ์ทางเชื้อสายที่เหนียวแน่น รวมทั้งการที่หมู่สมาชิกโดยรวมมีความสามารถที่จะ แสดงและเผยแพร่ความสำคัญของศิลปะการแสดงสู่สังคมทั่วไป

This article looks at an endangered traditional performing art of the Andaman Sea Coast of southwestern Thailand, rong ngeng, reflecting on its important, though largely forgotten role in the region's social history, and making note of contentious issues that have arisen in connection with its preservation (and preservation in general). Because similar conditions and dynamics exist for many other traditions around the region, the objective here is to ruminate on the viability of rural arts writ large, and to take a broad view of their place within the larger cultural "ecology." Using ecology as a framework to situate cultural practices helps emphasize the fluid nature and complexity of traditions in general-facts that may be overlooked when preservation efforts become too narrowly focused. This perspective allows us to step back, and see 
how performing arts can interact with the larger human ecology in a place or region.

Rong ngeng provides an interesting case for exploring the paradigm of human cultural ecology. As I discuss below, its development unfolded at a pivotal time in Andaman Coast society, when it rose to become the preeminent form of entertainment for more than a generation of people. Through its widespread popularity, it served to unite a predominantly rural populace of geographically and socially disparate communities found scattered among remote islands, and along mangrove-fringed coastlines, and rivers feeding from the interior. At its peak of popularity, rong ngeng groups crisscrossed the region, performing daily in all types of venues such as market towns and village commons. Its dissemination wrought changes to Andaman society writ large, as performers traveled to different communities from their own, and mixed with those who spoke different dialects and/or languages, and had differing belief systems. As they spread rong ngeng, they also found love, settled down, trained new cohorts of performing artists, and begat a new class of performers, some of whom became local stars. It is difficult to picture just how influential rong ngeng was during this time, particularly as its heyday lasted only until the early 196os, and then declined over the coming decades to become little more than a curiosity for most locals. Rong ngeng's post-heyday significance lies in the subtle legacies it bequeathed to subsequent generations and Andaman society and culture as a whole.

\section{$1 \quad$ An Ecology of Performing Arts Traditions ${ }^{1}$}

In the more familiar sense of the word, ecology is a biological matter, concerned with relationships between living things and their environments. Such relationships are dynamic. In the study of any living community, diverse organisms interact with and effect change upon one another: beings are born, live, procreate, die off, and at times disappear into extinction.

Similar processes and lifecycles can be observed in the study of cultural phenomena. Sutton and Anderson distinguish two dimensions within human ecology: human biological ecology, which encompasses the "study of the biological aspect of the human/environment relationship"; and cultural ecology, where the focus is on "ways in which culture is used by people to adapt to their environment" (Sutton and Anderson 2010, 3-4). We are concerned here with the latter type.

1 See the photos of this article at the URL https://doi.org/10.6084/mg.figshare.13265477. 
Writing in 1964 in the journal, Ethnomusicology, anthropologist/ ethnomusicologist William Archer discusses "an ecological approach [to music] in which a mobile, fluid, dynamic interrelationship with every other social aspect exists (sometimes transparently, sometimes not)" (Archer 1964, 28). In going beyond the sonic nature of the music itself, Archer suggests we "consider sources of raw materials for instruments, patterns of leisure, technological developments, [and] musical 'listening-spaces"' (Archer 1964, 28). These ideas found their way into the work of Archer's students, including Daniel Neuman whose 1990 book "The Life of Music in North India" contains a chapter entitled, "The Ecology of Hindustani Music Culture." In it, Neuman sets out "four general components of a music culture, in addition to the music itself: the producers of music, consumers of music, contexts of music events, and technology of music production and reproduction" (Neuman 1990, 203).

From those and other works, the notion that more could be understood about performing arts by looking beyond strictly aesthetic, visual, and physical properties-to include more social context about the communities that created them-became fundamental to scholarship on performing arts.

\section{The Performing Artscape of Thailand's Andaman Sea Coast}

In studying the ecology of performing arts traditions within a particular area, region, or virtual community, a first- and ongoing methodological step is to account for all qualifying practices-past and present. Analytically, as the list grows over time and available data on the individual arts becomes deeper and broader, the shared ecological relationships among related arts may become more apparent.

In southwest Thailand, for example, there exist a multitude of genres, which are interrelated in myriad ways. To the familiar eye, interconnections may be seen to occur when styles and repertoires are shared between different genres; when tunes or other elements are paired or juxtaposed; when performers are active in multiple genres, and carry their performing aesthetics back and forth; or when social, religious, or cultural functions serve to unite differing arts together. To employ a metaphor commonly used to describe rich, diverse arts ecosystems, constituent genres within a particular region form a tapestry: a term that, when employed in this regard, connotes manifold connections and relationships that flow in multiple directions, overlap, become blurred in relation to their putative "original" form, and sometimes transcend state or cultural boundaries via land, sea, or in virtual worlds. Another, perhaps more prosaic term that might be applied — though having less to do with aesthetics-is 
network. Evoking the sense of both tapestry and network, but with a bit more local character, is a Malay term (typically used for wood carving and other decorative arts): awan larat, which describes a meandering pattern of intertwining tendrils, flowers, and buds through two- and three-dimensional space. For the purposes here, awan larat might be thought of as a snapshot of the ecology of traditional performing arts, taken at any one moment.

A snapshot of the Andaman Coast that aims to inventory traditional performing arts in the region (as incomplete as it might be) includes several forms of dance-drama known as manora, nora pa, makyong, makyong laut/makyong $p a$, like $p a$, and like bok, which are all distinctive in their own right, but also can be seen as part of broader and shared Southeast Asian traditions. The region also has a multitude of genres of communally sung songs that include oral narratives, rhymes, and religious praise. They go by various names such as berana, phleng bok, plae dek, klongyao and hadrah/dara - the purpose here is not to go into detail about each, but merely to draw attention to the richness of the Andaman performing arts ecology. To continue, this inventory also includes (the aforementioned) rong ngeng and ramwong, which are two mixed-sex social dances, popular in the postwar years, with separate origins in Malay and Thai culture. There are local idioms of southern shadow-puppet plays known as nang talung or nang pa (for which nang is the skin used to make the puppets, talung, is likely a short form of Phatthalung Province, and $p a$, which translates directly as 'forest,' may be glossed as 'rustic.' The region also has Malay processional and martial arts music, gendang silat, played on long drums for weddings and circumcisions. Local Hokkien communities celebrate rituals-in particular the Ngan Jae vegetarian festival — with drums and percussion; Buddhist funerals often feature a Central Thai funerary music named for its principle instrument, the khong wong, a circular rack of gong chimes; or much rarer, the nearly extinct indigenous southern Thai funerary music, kalo. Our inventory also includes khong wong mon, a variety of khong wong, performed at shrines to propitiate indigenous jao thi 'guardian spirits.' To these we may add sung prayers and incantations of the religious traditions represented in the region (Buddhist, Muslim, Taoism, and indigenous animism); and work songs sung by farmers and fishers in the course of their labors. An comprehensive list would also include popular music like those heard in bars and at municipal fairs, which are not traditional per se, but have influenced, and in turn been influenced by more hoary performing arts traditions.

None of these forms may be seen to exist in isolation from the others, making the performing arts of the Andaman Coast region, as a whole, an awan larat of living, interconnected parts, deep complexity, and subjectively speaking, beauty. Their intertwined relationships interact and coexist at many levels 
and stages of their existence. Some, if not most, struggle for survival, and are driven to adapt to the times; some have disappeared entirely. The conditions for performing arts traditions are by no means exclusive to this region, but they lead to local questions (and answers) regarding their preservation. Ecology, without context or qualification, is a fairly neutral term, but becomes imbued with different meanings by different parties. Moreover, for a party to invoke the diverse cultural ecology of the region carries no implicit commission to preserve everything that exists within that area. It is merely a starting point and a dispassionate testimony that the cultural dynamics within that particular system deserve study and understanding.

\section{3 \\ Questions on Preservation}

From the researcher's perspective, it would be ideal if each of the abovementioned forms could be preserved and nurtured. However, expectations become tempered when one becomes aware of facts on the ground — so to speak — and confronts local issues surrounding preservation efforts. In practice, preservation is approached and carried out in an ad hoc manner, and may not address the ecology of performing arts as a whole.

One of the most formidable challenges is that preservation is an uphill battle. Traditional arts have been in broad retreat for decades, to the point that there are fewer and fewer surviving and active practitioners today, and appreciation for such arts has been in steady decline among the general population.

Preservationists - a broad term encompassing researchers, cultural activists, historians, dramatists, art lovers, or from other fields-are typically few in number. Their efforts to keep traditional arts alive and relevant are likely to encounter various limitations in terms of time, human resources, and funding. Their efforts are also subject to diverse views held by stakeholders who might have differing motives and views on methods and goals, and may or may not be involved in the preservation itself.

Specific questions surrounding preservation in the Andaman do not differ that much from those in other places within the region or further afield. The question of who are stakeholders is always relevant, and tied to who benefits from preservation efforts. Typically, the first to mind would be the artists/ creators themselves and their audiences. Beyond this nuclear group are outside patrons, including local cultural offices, other government institutions, corporations, and international cultural organizations (e.g., UNESCO), who might acquire stakeholder status, proportionate or not in some way to their contributions. They might share motivations, or their separate motivations 
may bring them into conflict. Their position and internal relationships might be colored by politics or economic interests or reflect some form of implicit or explicit hierarchy: insider or outsider, politically influential or weak, economically powerful or subservient.

The notion of preserving traditional performing arts in Southeast Asia can mean more than just supporting their economic or cultural viability against an onslaught of large-scale transformations to entertainment markets and popular media over a half-century or longer. Stakeholders within the Andaman today might also be surrogates of larger ideological or social movements that aim to control or appropriate preservation efforts. In this regard, let us consider contemporary Islamic movements in Southeast Asia as being stakeholders for our purposes, though with motivations and goals that are often in opposition to preservation.

Conservative Islam, as a greater movement, has been zealous in its opposition to traditional practices. It argues that they are on the whole, syirik, an Arabic term meaning a polytheistic, thus forbidden practice. Its evangelists openly call for the eradication that music and other performing arts. Although puritanical threads of Islamic thinking have existed in Southeast Asia since the nineteenth century, if not earlier, the modern version of austere and doctrinaire Islam became more prevalent in southern Thailand and Malaysia around the early 1970s, when the transnational, South Asian-based group, Tablighi Jama'at began intensive missionary work $\left(d a^{\prime} w a\right)$ there (for more on the Tablighi movement in southern Thailand, see Horstmann 2007 and Noor 2012). Thus, discord between traditional performing arts and the Islamic establishment is a relatively recent phenomenon, and took place within the living memories of many older practitioners.

Conservative Islam should not be blamed as the sole factor for the deterioration of traditional performing arts. Local communities allowed their traditions to disappear for other reasons, and understanding why should inform preservation efforts. As influential as the Islamic mission has been, the decline of traditional performing arts can also be attributed, in part, to the rising prevalence of State-run and commercial broadcast and recorded media over a half-century. Through these channels, a pan-Thai identity—modern and nationalistic in outlook - was shaped, practically venerating concepts such as "developed" (kan phatthana) and "contemporary" (thansamai). Traditions were looked upon as backward; traditional performing arts could not compete with radio, film, and TV.

As Weapons of the Weak vividly illustrates (Scott 1985), rural Malay society in the 1970s saw large-scale modernizations to traditional rice-farming practices. This "Green Revolution" was contemporaneous with changes taking place, 
only hours away, across the border in southern Thailand. Both agricultural revolutions led to crops that required year-round attention. Consequently, with little time for off-season pursuits, peasant farmers had less time to recreate, and less incentive to make performing arts a career, as agriculture provided a steadier income and was more secure.

Consider as well the biases stakeholders might bring with them to these endeavors. A researcher's bias is not necessarily intentional, malevolent, or discriminatory, but the relationship one has with the subject of study can lead to developing particular favorite groups, music types, styles, or performers. The notion of a particular performance being "inauthentic" is not typically a neutral view, but there those (among all types of stakeholder) who believe that traditions should be of a certain type and immutable. The fact that grassroots performers hold varying ideas of what changes are acceptable, and they often are the ones to create non-traditional innovations.

This difficulty in defining a tradition is something we encounter in the aforementioned rong ngeng. This popular social dance-music genre came to the Andaman from Malaya as ronggeng in the 1930s, where it was the trend $d u$ jour. Ronggeng spread from the multicultural port cities of colonial Malaya in all directions; its novelty made it welcome in surrounding rural areas as something fresh and modern. Southwestern Thailand is a case study in this dissemination. Locals learned to play and dance this urban and cosmopolitan pastime, and soon localized ronggeng — and folk-ified it —into a distinctively Andaman idiom. They added new tunes, sang in the southern phaktai dialect (rather than the original Malay), and incorporated indigenous traditional practices into their performances, reflecting local beliefs and cultural idiosyncrasies. This idiom is known today as rong ngeng (from ronggeng) or phleng tanyong 'tanyong song' (Ross 2017, 68). It is recognized widely among locals, making it something of an icon and distinctive symbol of Thai-Andaman identity, despite being a relatively new tradition, and one which diverged greatly from its principle antecedent, Malayan ronggeng. In this regard, it is a tradition that might challenge the immutable concept of "traditional" that some hold.

\section{What Motivates Preservation Efforts?}

The following section looks at some broad types of motivations for preserving traditional performing arts, and then examines these cases on the ground, in the Andaman. Motivations for preservation can be as numerous as the stakeholders themselves. Some are driven by the cultural identity and pride embodied in the art. Or, perhaps, as vessels of heritage that provide invaluable insights into the past; as artifacts that aid in the reconstruction of historical knowledge. 
Some by the potential exploitation of its commercial value (the idea of art as intellectual property). For some, traditions may be drawn upon, borrowed from, stolen, or cannibalized, as the raw building blocks for the artistic works of today and tomorrow. And, as discussed earlier, some are motivated to eradicate the arts as part of a religious crusade.

\subsection{National Culture}

From the postwar era onward, Southeast Asia's national governments have often used traditional arts to model shared national culture and mobilize them in the formation of a unified citizenry. With the transition from absolute monarchy to the mix of political systems we know today, governments took over the maintenance, development, and dissemination of arts (and arts discourses) from their previous patrons, the palace.

This was the case for Thailand beginning around the 1930s. One result was that certain elite arts - previously limited to elite audiences - became increasingly accessible to the general public; and conversely, folk arts traveled in the opposite direction, becoming adopted into elite and official circles. Both helped integrate the citizenry to a shared cultural identity. From that period onward, schools, state-funded cultural centers, and the media, became places for the public to encounter and learn erstwhile court music, dances, and theater, to which they had not had access previously.

An example of the latter movement is ramwong, which emerged during that era. What began as a provincial folk dance, with roots in the Thai heartland, was recast by the national government, beginning around the late-193os to early-1940s, with a modern repertoire, designed to inculcate the populace with nationalistic values. It was disseminated and promoted throughout the country under the rather generic name, ramwong 'circle dance.'

This type of project, the-arts-as-national-identity, was common throughout Southeast Asia. In neighboring Malaysia, for example, the national government assumed authority over arts and culture through a National Cultural Policy (1971), which aimed to both unite the people of the young nation (independent in 1957), but to also define and segregate the major ethnic groups through the circumscription of what types of performing arts traditions belonged to each.

\subsection{Religion}

Events in recent decades in the northeastern Peninsular Malaysian state of Kelantan shows how religious motivations overlap with, and provide a counterpoint to state intervention. They are also a cautionary tale of unexpected outcomes. In contrast with cases stated earlier, where states play the role of chief benefactors to the arts, early 1990s Kelantan banned most performing 
arts traditions under pretexts of Islamic law (see Hardwick 2014, 41). An upshot of this policy was that numerous Kelantanese performers relocated to the nation's capital, Kuala Lumpur. There, they took positions within the national arts academy and government cultural offices where they were able to continue teaching and developing their arts, and in an ironic twist, several of their provincial art forms grew to become national paradigms of Malay culture (most notably, wayang kulit shadow play and makyong dance-drama). In the elevation of Kelantanese arts to a national level, Kelantan's loss became Malaysia's gain (though Islamists might argue otherwise); however, there were other outcomes that might be seen as tied to the Kelantan-to-Kuala Lumpur arts migration: as Kelantanese arts took an oversized role within the academy, other regional idioms became overshadowed as a result, to the latter's detriment.

\subsection{Commodification}

In southwest Thailand, despite some increased recognition among the public of the potential cultural and economic values of traditional performing arts, they do not occupy a central place in one's quotidian life. Exposure to the arts is, at best, occasional. There are public performances at municipal festivals, Buddhist temples (wat), tourism promotions, or private functions (e.g., weddings). This is not unique to the Andaman, and might be seen as fairly typical for the whole of Southeast Asia, where commodification of the traditional arts has been modest at best, though with exceptions, such as Indonesia, which has generally been more successful at promoting them. Indonesia's public and private sectors have pioneered the promotion of cultural heritage as intellectual property, sometimes motivated by a concern that their arts were in danger of being appropriated by outsiders. Their rows with Malaysia with whom Indonesia shares common land and sea borders, languages, ethnic groups, and cultural practices, have been frequent over recent years. They accuse Malaysia of appropriating, inter alia, traditions that include batik textiles, indigenous music (e.g., the gordang sembilan of North Sumatera, see Abdussalam 2012), folk songs (e.g., "Rasa Sayang"), traditional dance (Mandailing tor tor and Balinese pendet), and a spectrum of styles of martial arts (known collectively as pencak silat). In contrast, Malaysia and Thailand—though also immediate neighbors with numerous shared performing arts traditions in their overlapping cultural spheres - have not seen public disputes over ownership on the level of Indonesia-Malaysia antagonisms. If anything, this may just be an indication that the economic potential for those arts is still under exploited at present.

Traditional performing arts do occasionally travel beyond the borders of the Andaman. For example, when they make cameos in popular music recordings, videos, and TV productions. One might need to pay close attention to 
the popular music heard on Thai radio or television to observe this. You might hear a plaintive $p i$ 'Thai oboe' melody, an interlocking hand-drum rhythm, dance, or elements of regional costume. Typically, they are not much more than an added exoticism grafted on to formulaic pop songs. And despite the commercial nature of the music and the appropriations, none of these appearances provide much in terms of economic boon to Andaman performing arts or artists. Rather, they are more exemplary of an exploitative relationship in economics and culture that exists in interactions between the urban and the rural. (Going further, I would suggest the urban-rural divide is a mirror of past colonizer-colonized relationships, whereby the extraction of raw materials from the hinterlands goes mainly to the benefit of the elite in cities and trading centers.)

\subsection{Embedded Knowledge}

Lastly in this section, regarding the stakeholders who appreciate the intrinsic historical and cultural knowledge found within traditional arts, and seek to preserve them for their otherwise unrecognized value, are the cultural activists and academics who are drawn to the appeal of the traditional arts. Although stories in a performed tradition (such as dance dramas like like pa or manora) do not provide empirical historical data, per se, they can provide some alternate sources, clues, or fill in some blank spaces when nothing else is available. Ideally, such traditions are laden with pearls of wisdom: neither deems as factual, nor dismissed as unreserved fiction. In my own Andaman Coast-related research, I found the sources to be almost always in oral form, and very rarely in print. One might attribute this paucity of printed accounts in the Andaman to the region not having had a major royal center in recent centuriesin contrast with neighboring early-modern kingdoms, Ligor, Singora, Patani, and Kedah - thus, autochthonous court chronicles, local literary traditions, or other similar materials that are sources for historical data elsewhere, are rare or non-existent there.

Given the dearth of indigenous writings on the Andaman, past and present, the piecing together of oral histories regarding performing arts helps inform insights on social and economic trends of the past. They can be powerful, though under-utilized sources of cultural and historical knowledge. Rong ngeng and ramwong, for example, have been useful in showing a nexus between performing arts and society at a time when modernity was just arriving to the region. Both arrived when the region was transforming from an underpopulated backwater to a growing powerhouse for agriculture, commercial sea products, mineral extraction, and later, tourism. Oral histories surrounding those two dance genres inform the migrations of human labor from elsewhere in Thailand or Malaysia; how people from different languages and cultures met 
and mixed; how newly available disposable income transformed the complexion of entertainment, as well as the market for material products; and they tell about the entertainment complex as a whole, and how performers, genres, and styles saw their opportunities change or disappear. In a larger sense, viewing entertainment culture through the voices of its participants helps paint a picture of a nascent shared identity that bloomed over the passing decades.

As illustration of the previous, an oral history of rong ngeng helps fill in the lacunae of knowledge about an under-documented area - the Andamanand helps us better understand what motivates cultural preservation there. When rong ngeng first arrived to the Andaman Coast in the 1930s, it was a cosmopolitan import from a multicultural part of Malaya, and a common form of entertainment throughout the Malay-speaking world (known as ronggeng). Ronggeng was a particularly vibrant cornerstone of the night time entertainment scene on Penang Island, located to the south of the Thai Andaman Coast, and one of its principle markets for charcoal and other goods produced in the latter. From Penang, ronggeng percolated outward into the neighboring region.

One of its "currents" carried it northward by sea, initially in the hands of only a small cohort of itinerant performers. One of these players, a violinist named Abu Qasim, landed in a small fishing village on Lanta Island, Krabi, in the mid-1930s, where he proceeded to train a generation of home-grown musicians and dancers as performers. That small community on Lanta became the central hub for what quickly grew to become an Andaman Coast-wide rong ngeng entertainment trend. At the peak of its popularity during the postwar decades (from roughly the late 1940s until the early '6os), local troupes, typically comprising a violinist, two frame drummers, and a gong player, along with one or more singer-dancers, were established in all major island and coastal communities between Satun and Phuket.

Rong ngeng was performed as it was in Penang during that time, as a form of taxi dance-meaning a mixed-couple dance in which one party (typically the male) pays for the opportunity to dance with a female professional singer-dancer (see Cressey's 1932 work on Chicago dance halls for perhaps the earliest use of this term). Rong ngeng dances were held at private homes, in markets and other public spaces in villages and towns. The groups that began on Lanta, and later took root elsewhere, were often peripatetic, traveling during low seasons for fishing or agriculture, and maintained a simple 


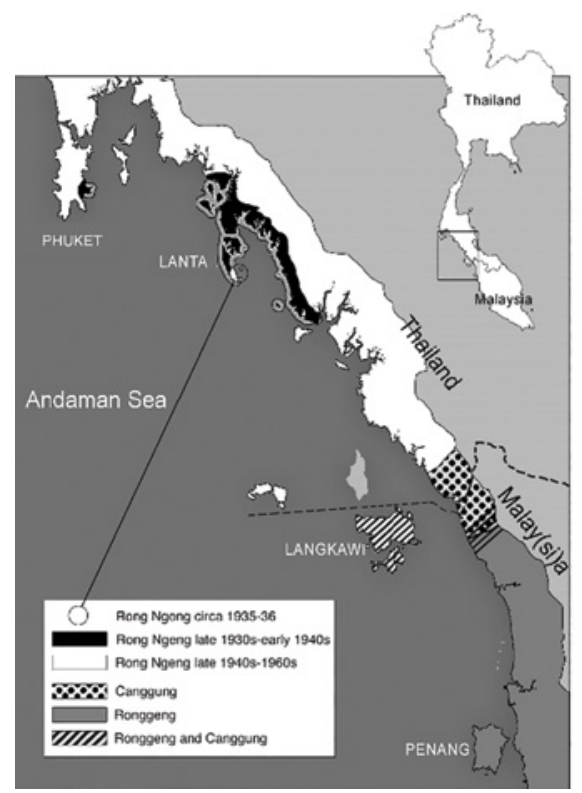

\section{GROWTH AND DISSEMINATION OF RONG NGENG ON THE ANDAMAN SEA COAST 1930s - 1960s}

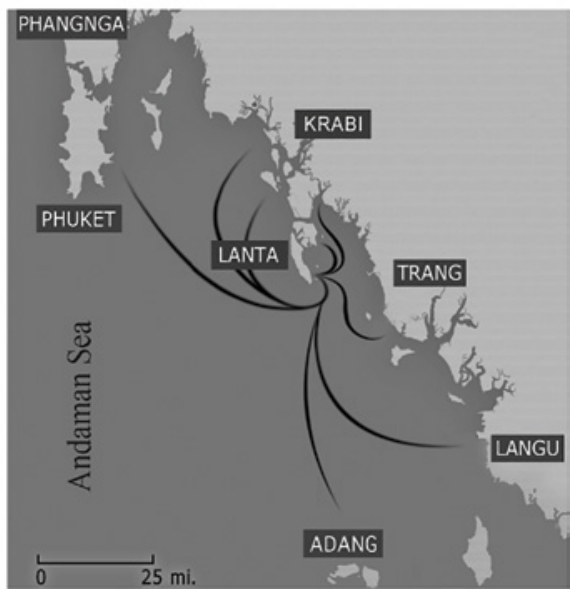

FIGURE 1 Postwar Growth and Spread of Rong Ngeng (maps and keys by Lawrence Ross)

economic model, where they collected small fees for each dance from the attendees.

Despite being widely popular, indeed preeminent, in its heyday, and sustaining the livelihoods of numerous troupes throughout the region for years, rong ngeng never expanded beyond its rural milieu, and unlike its contemporaries, ronggeng in Malaya, and ramwong and luk thung in Thailand, rong ngeng was never recorded to gramophone disk, or broadcast on the radio. There are, however, anecdotal cases in which it received brief exposure outside of the region. In the mid-1950s, Bida Chaipet, a teenager at the time, traveled with her mother and other first-generation Lanta rong ngeng performers to Bangkok at the invitation of the local Krabi parliamentarian. She recounted to me (in a personal correspondence in Hua Laem Village, Lanta, Krabi, on 8 December 2007) how they performed at Lumpini Park for several nights, recalled the raucous soldiers that kept trying to climb up onto the stage with them, and that Lanta provided groups for two subsequent trips to Bangkok in later years. Despite this exposure, the government patronage that brought the groups there did not help rong ngeng grow beyond the Andaman borders.

After the postwar heyday, rong ngeng declined as a popular trend. The youth of the newer generation were moving on. Around 1960, ramwong began supplanting rong ngeng as the favorite social entertainment in towns and villages. 
To remain economically competitive with ramwong, some rong ngeng groups began to play ramwong tunes, and some switched to playing ramwong exclusively. In retrospect, this shift from the Malay rong ngeng to Thai ramwong can be seen as an early indicator of a larger, long-term social transformation affecting the borderland region from that era onward. Throughout the region, as postwar nationalist ideologies and more centralized culture were disseminated, cultures of the intermingled border areas such as the Andaman gradually began to disappear. And for the Andaman, in the middle of the postwar expansion of nationhood in Southeast Asia, this transition from rong ngeng to ramwong epitomized an ebbing of Malay media and culture, and the rise of a pan- (i.e. Central) Thai character.

Rong ngeng did not disappear entirely; some performers continued into the 1970 and 8 os, but it became saddled by negative associations that were becoming attached to ramwong: a reputation for connections to drinking culture, promiscuity, fighting, and other vices. In some municipalities, the banning of ramwong (for the aforementioned reasons) also extended to rong ngeng. Other factors contributing to the decline of rong ngeng as well as other performing traditions over the latter decades of the twentieth century, included changes to the media, forms of transportation, and new technologies. One of the most pernicious, however, was the rising tide of Islamic conservatism-mentioned earlier - that took root in the early 197os and resulted in waves of transnational Islamic missionary groups (most active were the South Asian lay activists, Tablighi Jama'at) saturating the entire south of Thailand. Tablighi activities preceded a rise in moral opposition toward all types of non-religious social entertainment, as well as other ostensibly non-Islamic cultural practices. Andaman rong ngeng, by the 1990s, was only barely surviving. Just at its nadir, it began to see a turn-around with a modest revival over the following decade, led by a handful of active groups, comprised mostly of practitioners from the postwar cohort and their descendants. In the larger scheme of things, this revival may be seen to correspond with a palpable increase in awareness of, and interest in regional culture around Thailand. This has been evident in the flowering of regional languages and dialects, foods, and cultural traditions from the provinces.

\subsection{Extant Rong Ngeng: The Island Style}

Rong ngeng oral history reads like a chronicle of the postwar era of transformations. In all, three distinctive rong ngeng styles can be identified among the extant performers today. The oldest, and often referred to by locals as the most dang derm or ton chabap ('authentic,' roughly glossed), is the Malay-language style of the islands where rong ngeng, as mentioned earlier, first took root. The 
first version of rong ngeng in Thailand was originally shared by Malays, Orak Lawoi 'sea people,' Thais, Chinese, and those of other backgrounds. Today, this "island style" of rong ngeng today is almost exclusively performed by the Orak Lawoi ethnic minority. They are guardians of the repertoires of music and dance, and they retain the aesthetic features from the 1930s and ' 40 s on Lanta Island. They are also the most infrequent to perform of the extant groups, and the most endangered as well: as elder musicians pass away without replacements, rong ngeng is becoming even more rare, and the performances that do take place are mostly for tourists, and exist only as shadows of the original dances, performed to prerecorded music.

\subsection{Extant Rong Ngeng: The Indigenous Tanyong Style}

A second extant rong ngeng style-developed along the Thai-speaking mainland after its prior introduction to Lanta-is a significant branch of the greater Malayan ronggeng complex, and deserves recognition for its expressiveness and artistry. Typical to Thai-Muslim communities, this form is a unique idiom sung in Southern Thai (pak tai), with a unique lyrical style based loosely on the Thai klon poetic form, and a distinctive song repertoire (known as phleng tanyong or 'tanyong song'). Although tanyong existed as a taxi dance in the past (like the island style), today's tanyong groups perform almost entirely for staged cultural show events. Conscious of the negative associations of the past, tanyong is promoted as more of a symbol of traditional local culture and identity than as social entertainment. Its performers (now mostly middle-age to elderly Muslim men and women) actively mediate with the conservative religious class to soften the latter's opposition.

\subsection{Extant Rong Ngeng: the 'Thansamai' or 'Ramwong' Style}

A closely related counterpart to tanyong, and the third extant rong ngeng form, is the thansamai 'modern' style of rong ngeng, sometimes also referred to as the ramwong style. In a Venn Diagram of rong ngeng song repertoire, thansamai and tanyong styles have the greatest amount of overlap. But, perhaps because of its aesthetic contrasts, traditionalists lament the thansamai style as being too modern and lacking in the art and beauty of the rong ngeng of earlier generations. Rong ngeng thansamai does, however, retain a feature of old rong $n g e n g$ that has otherwise disappeared from first two styles; it remains a taxi dance, and at its events one may witness participation by young and old, with audiences transcending ethnic and religious boundaries. What makes this style so attractive to some, and rejected by others, is perhaps, how it challenges strict social mores. At village performances, rowdy male youths are ubiquitously present; young women professional dancers wear t-shirts and short skirts 
and perform suggestive dances for their partners, or tables of people seated as an audience. Though its reputation causes consternation among conservative Muslims, one still can observe Muslims in pious garb-men in skull caps, women in headscarves and veils - attending and participating, as if they are excused from their religious codes for just one evening.

\subsection{Preserving Rong Ngeng}

The two most common questions regarding the preservation of rong ngeng hinge upon its economic viability and the types of patronage that will continue to support its survival. As with most performers of folk traditions, local rong ngeng performers are more likely to receive support from local government institutions than from national-level organizations - the local part is generally from provincial or district cultural offices (sûn watanatham) or sub-district administrative agencies (ongkan borihan suan tambon), whose mandates extend to sponsoring activities for locals and tourists, and in many ways keeping traditional arts alive today. Most performance opportunities today can be seen as having some direct or tangential relationship with the government: through public universities, municipal fairs, tourism promotions, or cultural exhibitions, to name a few State or local institutions that provide support. Demonstrating the lack of national support for rong ngeng to-date is the fact that no Andaman rong ngeng performer has been officially recognized as a National Artist (sinlapin haeng chat). This lies in contrast to other well-known traditional performers in the south from genres including manora, nang talung, the historically and distinct Pattani-style rong ngeng, and other southern arts who have received that recognition. An interesting area of involvement where a government institution has met traditional performers has been in local primary and secondary schools in the Andaman, where, for extracurricular activities, they have occasionally hired local players to train students and arranged performances. This was not accidental: several local school principals with whom I have spoken said this satisfies a general, albeit hazy requirement to provide "local syllabi" (laksut thongtin) to their students.

Outside of cultural shows, local activities, festivals, and schools, the general public is unlikely to encounter rong ngeng in their daily lives. Taxi dances have dwindled to infrequency in recent years, meaning the era in which rong ngeng was a participatory event uniting performers with audiences is likely drawing to a close. In terms of recorded media, it is possible to happen upon a video disk of rong ngeng in a record store or night market, or hear a local radio broadcast a rong ngeng song, but the opportunities to be exposed to this art form are becoming fewer and fewer, and the likelihood is that the genre will soon recede into history. 


\section{Concluding Thoughts}

Despite the fact that the average Andaman resident knows little, if anything about rong ngeng, few performance traditions in Southeast Asia have left as profound an impression upon a society as rong ngeng did for an entire region. Its heyday took place during a pivotal time: at the dawn of mid-twentiethcentury modernity and development that came to transform many a rural backwater in Southeast Asia. Since then rong ngeng has become an emblem of local color and flavor, and a symbol of a popular entertainment that unified the greater Andaman community during that period of growth and development. In a sense, it is a founding pillar of contemporary Andaman identity. Though it has receded from the public's consciousness with the passing of time, vestiges of rong ngeng - in the vocal timbres of Andaman singing, the sway of dancers' arms, legs and torsos, and clever poetic interplay — remain diffused within the region's performing arts as legacies today.

To best understand rong ngeng's important role, the recollections of those who witnessed and participated in it are the most valuable sources still available. These people constitute a body of oral history that is as broad as it is deep; collectively encompassing thousands of personal accounts, spanning generations, and standing as an intricately woven chronicle of the changing Andaman society over roughly eight decades.

However, rong ngeng's slow disappearance creates a conundrum: despite being a cultural icon of Andaman identity, most people are indifferent to its preservation. The government does not give it due recognition; the religiously pious are still contemptuous of it. It does not captivate the youth of today as it did for prior generations. It offers little economic potential for luring local or outside investors. And rong ngeng exists today only because it has been kept alive by an aging cohort of performers. The inescapable truth for rong ngeng, as with many other performing arts traditions today, is that the human cultural ecology paradigm, by design, does not sustain any argument for preservation. It just stands as a theoretical framework allows for the possibility that any piece of cultural heritage — no matter how influential — could completely disappear, becoming extinct, as in the biological sense. A Darwinian survival of the fittest-type outcome. Understandably, this is not a desirable result to those who value the beauty and meaning found in traditional arts, and mourn the loss of local history and identity, but we must be realistic that the forces of preservation are sometimes insufficient.

Outside of sustained cultural activism, which may continue to an uphill battle to preserve rong ngeng in certain corners of the Andaman, there is some reason for optimism if we take a "macro" view of the local ecology. Even if 
and when traditions die out, new ones subsequently arise, and to some degree, they often retain elements from their antecedents. Based on past precedent, we could surmise that human creativity operates in a similar manner to physical laws. We might call this the Human Cultural Ecology Corollary to the Law of Conservation of Mass, and opine that creativity (or creative potential) is neither created nor destroyed, but only changes form. Thus, the notion of ecology is helpful here as it stipulates that for any region, culture is fluid but interminable.

Andaman rong ngeng has itself changed form over the years to maintain vibrancy, which is what bequeaths us the different styles extant today. The three addressed above diverge not only stylistically, but also in terms of where they find their economic sustenance, and how they interact with government and/or religious establishments. In other words, each has its own place within the human cultural ecology of the Andaman Coast.

\section{References}

Abdussalam, Andi. 2012. "Malaysia Not to Claim Tor-Tor Dance as Its Own?" Antara News, June 21. Accessed March 8, 2014. http://www.antaranews.com/en/news/ 82988/malaysia-not-to-claim-tor-tor-dance-as-its-own.

Archer, William Kay. 1964. "On the Ecology of Music." Ethnomusicology 8 (1): 28-33.

Cressey, Paul Goalby. 1932. The Taxi-Dance Hall: A Sociological Study in Commercialized Recreation and City Life. Chicago: University of Chicago Press.

Hardwick, Patricia. 2014. "The Body Becoming: Transformative Performance in Malaysian Mak Yong." Music and Medicine 6 (1): 40-8.

Horstmann, Alexander. 2007. "The Tablighi Jama'at, Transnational Islam, and the Transformation of the Self between Southern Thailand and South Asia." Comparative Studies of South Asia, Africa and the Middle East 27 (1): 26-41.

Neuman, Daniel M. 1990. The Life of Music in North India: The Organization of an Artistic Tradition. Chicago: University of Chicago Press.

Noor, Farish. A. 2012. Islam on the Move: The Tablighi Jama'at in Southeast Asia. Amsterdam: Amsterdam University Press.

Ross, Lawrence. 2017. "Across Borders and Genres in Malaysia and Thailand: The Changgong Rhythm of the Andaman Sea Coast." Asian Music 48 (1): $5^{8-84}$.

Scott, James C. 1985. Weapons of the Weak: Everyday Forms of Peasant Resistance. New Haven: Yale University Press.

Sutton, Mark O., and E. N. Anderson, 2010. Introduction to Cultural Ecology. Plymouth, United Kingdom: AltaMira Press. 